\title{
Józef Suda
}

dr inż.

Zespół Sterowania Ruchem Drogowym,

Zakład Sterowania Ruchem,

Wydział Transportu Politechniki Warszawskiej

jsu@wt.pw.edu.pl

DOI: 10.35117/A_ENG_17_02_05

\section{Misstatements of GPS- location of public transport vehicles in Warsaw}

\begin{abstract}
The article presents the results of the accuracy of the location of public transport vehicles in areas with varying degrees of urbanization. Typical sources of errors in the satellite location systems have been analyzed. The influence of external factors and conditions resulting from the development of GPS receiver technology has been evaluated. The accuracy of location Warsaw trams and buses belonging to the largest public transport operator in Poland (MZA Sp. о. o. in Warsaw) was evaluated.
\end{abstract}

Keywords: Public transport; Location; GPS

\section{Vehicle location methods}

Public transport companies (TPs) in most major cities, as well as transport companies, have fleet management systems. The typical hardware configuration of the vehicle management system includes devices installed in vehicles, communication centers providing data transmission and audio communications, dispatch centers responsible for proper performance of targets and road infrastructure equipment for control, information and transmission facilities [8]. The accuracy of these data directly affects traffic management processes, so it is important that the data is as small as possible. Innovative technologies used to locate vehicles have made the positioning accuracy is increasing.

This chapter presents the most commonly used methods of locating vehicles in public transport:

- logical location,

- point location,

- location of SIM card in GSM system,

- location in satellite systems.

Logical location method. It consists of counting the traveled distance, usually by a device coupled to the vehicle's gearbox, generating pulses per meter. For passenger information, the distance from the previous stop is counted, where the counter is zeroed. Information is required on the currently performed transport task, course route and distance between stops.

The logical location only functions when the vehicle is moving on the route described above. Reducing the route causes the position of the vehicle to be inaccessible. The advantage of this method is independence from road infrastructure, radio, space, etc.

Point location. It consists in determining the presence of a vehicle in a strictly defined route. It is more accurate than the logical location. The first method was the use of bar codes, that is, a graphical representation of a string of numerical symbols through a combination of dark and light bars (Figure 1). The vehicle registers its presence at a specific registration point on the route. The information is sent to the location system operator. Based on them, you can calculate the travel speed and forecast the future location of the vehicle. 


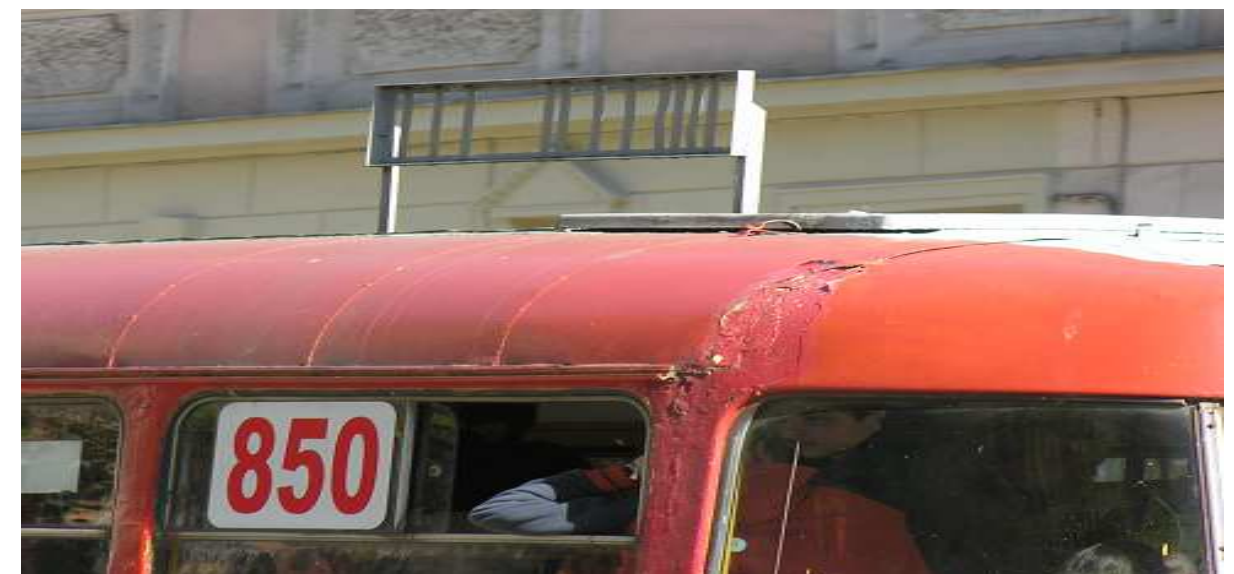

1. On the roof the code to register the vehicle at the registration point (Lviv, photo author)

Currently, spot-based methods use image recognition or radio signals. The OCR (Optical Character Recognition) technique uses electro-devices for the automatic reading of printed characters. Laser, diode, omnidirectional readers are used for reading. Radio frequency identification (RFID) is a radio frequency identification method [5]. This method allows remote identification of the identifier, which is stored in a special electronic system.

GSM system. Global System for Mobile Communication is the world's most popular digital mobile standard [6]. The GSM network operates by registering a Subscriber Identity Module (SIM) card so the subscriber card, at the nearest base station. The geographic location of the card enables the identification of the position of the GSM (Cell-Id location) relay station [10]. EOTD (Enhanced Observed Time Difference) and TOA (Time Of Arrival) methods are based on signal propagation time. In the first one is used differences in time measurement from several stations, and in the second measure the time to reach the station with an atomic time pattern. The AOA (Angle Of Arrival) method analyzes the propagation angle of the signal by the multi-tone systems.

Tab. 1. Misstatements of vehicle location in GSM telephony systems [6]

\begin{tabular}{|c|c|c|c|}
\hline $\begin{array}{c}\text { Place of } \\
\text { measurement }\end{array}$ & $\begin{array}{c}\text { Average location } \\
\text { misstatement }[\mathbf{k m}]\end{array}$ & $\begin{array}{c}\text { Maximum misstatement } \\
{[\mathbf{k m}]}\end{array}$ & $\begin{array}{c}\text { Standard deviation } \\
{[\mathbf{k m}]}\end{array}$ \\
\hline City center & 0,44 & 2,40 & 0,41 \\
\hline Highway & 2,92 & 20,37 & 2,02 \\
\hline
\end{tabular}

The accuracy of these methods depends on the expansion of the network and the availability of the station database. The error values are shown in Table 1. All methods, apart from the propagation angle measurement method, can be improved by using new terminals in the terminals.In terms of operating principle, the Satellite Locations Systems can be divided into three groups [2]:

- $\quad$ systems for measuring angles,

- angular-distance systems,

- Distance, radial distance or radial distance measurement system.

Now fully operational are two global systems GPS NAVSTAR Global Positioning System (NAVigation Signal Timing And Ranging) - American system, GLONASS (Globalnaia Navigacionnaia Sputnikova Sistema) - Russian system, two more, Galileo and Beidou are under construction [2]. These systems are commonly referred to as GNSS (Global Navigation Satellite Systems). Their principle is to measure the distance of the satellite from the receiver. There are different ways of coding the signal, system times and reference circuits. 


\section{Satellite location misstatements}

The segmental construction of satellite navigation systems means that each of its components is exposed to other factors that may generate errors. Due to the area of activity and the reasons for their emergence, they were distinguished [2]:

- factors affecting the space segment,

- propagation distortions,

- factors relating to reception apparatus,

- geophysical phenomena.

The space segment is influenced by: the gravitational field of the Earth, the interaction of celestial bodies, solar radiation, electromagnetic interactions, atmospheric resistance and the occurrence of relativistic effects. Signal propagation errors are caused by changes in the radio wave in the material center. Changes may be made to the speed, frequency or polarization of the wave as a result of the earth's atmosphere passing through, in particular by the ionosphere and the troposphere.

Multi-latency error occurs when the user's receiver receives a reflected signal from different surfaces, often repeatedly. In this situation, the waveform is distorted, polarized or weakened. These factors increase the signal arrival time and location error. This misstatement is related to land development.

Receiver errors depend on the class and destination of the device. The most common are software errors and electrical circuits. Limits of accuracy are information times in the receiver itself, such as the signal from the antenna to the processor or the processing time in the processor. The receiver can also produce noise that interferes with the proper reading of the data.

The paper presents the results of the research: influence of signal diversity, errors arising in receivers and atmospheric factors, accuracy of location of GPS receivers.

Identifying factors that may influence the accuracy of the location provided the basis for formulating criteria for the selection of measurement polygons such as:

- type of land (the nature of the building),

- $\quad$ presence of public transport vehicles equipped with a GPS receiver,

- possibility of identifying the generation (age) of the receiver,

- possibility of determining the actual position of the receiver.

Differences in the distance of the actual position of the receiver (vehicle) from the position acquired from the location using the GPS receiver are treated as an error.Due to the availability of data, the analysis of the location of vehicles of Miejskie Zakłady Autobusow Sp. z o.o. in Warsaw and Tramwaje Warszawskie Sp. z o.o.

\section{Method of evaluation of the MZA buses location}

Position data buses are determined by the GPS receiver on board the vehicle and transmitted using the GSM GPRS system to Central Traffic Supervision MZA. Location information is collected for the purposes of the Emergency Communications Systems (SŁA), Deviation, and Accidents and Failures (WiA), which constitute the subsystems of the MZA Traffic Management System [9]. 


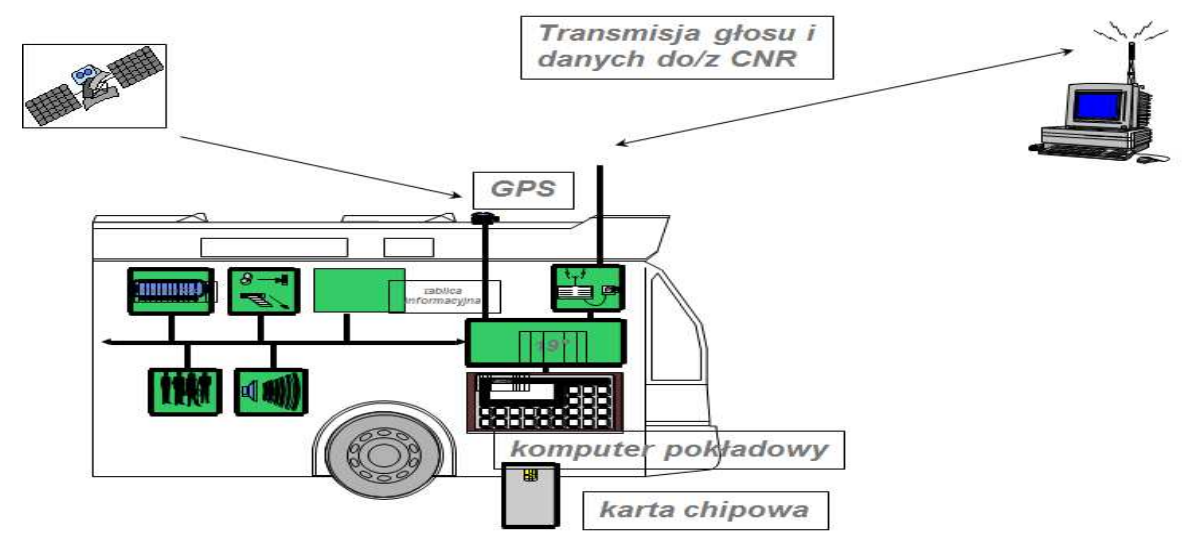

2. Location, communication and passenger information systems on the bus [5]

The device mounted on the vehicle, sends in about 10 seconds, telegrams containing information on, among others the number of the GPRS device (imsi), the SIM card number in the vehicle (imei), the time, the geographical coordinates and the ID of the device. Examples of telegrams are shown in Fig. 3.

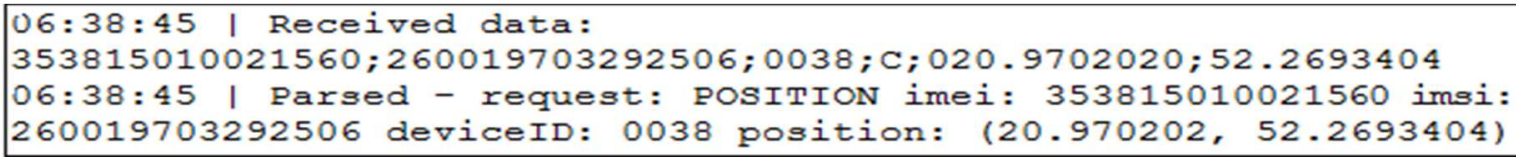

3. Telegram sent by the bus containing the location of the vehicle [9]

At each location, based on the satellite map, a line equation describing the expected route of the bus was determined. The location error was the distance of the point (GPS receiver in the vehicle) from the reference line. The position error was calculated in degrees from the pattern at the distance of the point from the straight line:

$$
d=\frac{\left|A x_{p}+B y_{p}+C\right|}{\sqrt{A^{2}+B^{2}}} \quad\left[{ }^{\circ}\right] .
$$

Then converted to radians and meters, assuming that the Earth is a sphere, the distance from the point of the straight line is defined as the arc length.

$$
\begin{aligned}
& \propto=\frac{d * \pi}{180^{\circ}} \quad[\mathrm{rad}] \\
& D=\frac{\alpha}{360^{\circ}} * 2 \pi R=\frac{\alpha \pi R}{180^{\circ}} \quad[\mathrm{m}]
\end{aligned}
$$

where:

$\mathrm{d}-\quad$ distance from a point to a line $\left[^{\circ}\right]$,

A, B, C-coefficients of linear function written in general form,

$\mathrm{x}_{\mathrm{p}}, \mathrm{y}_{\mathrm{p}}-$ The coordinates of the point where the bus was located.

$\alpha$-distance from a point to a line [rad],

$\mathrm{D}$ - distance from a point to a line [m],

$\mathrm{R}$ - the average radius of the Earth $(6371000 \mathrm{~m})$.

Five research polygons located in Warsaw were selected. They were:

- Trasa Lazienkowska section between ul. Marszałkowska and Al. Ujazdowskie,

- a section of the route on the Silesian-Dabrowski bridge, 
- end of bus lines - Central Station,

- end of bus lines - Metro Marymont,

- $\quad$ end of bus lines - Górczewska Housing Estate.

Each bus stops at a specific stop. It was possible to determine the distance of the actual stopover from the location obtained using GPS.

\section{Method of evaluating the trams location}

In Warsaw there are two systems using the location of the tram. There are Passenger Information System (SIP) and Tramway Monitoring System (SNRT2000). Data sent from vehicles was used to evaluate the location within SNRT2000. The flow of information between the various elements of the System provides radio channels ranging from 410 to $430 \mathrm{MHz}$. The Communication Center supports both data transmission and voice communication.

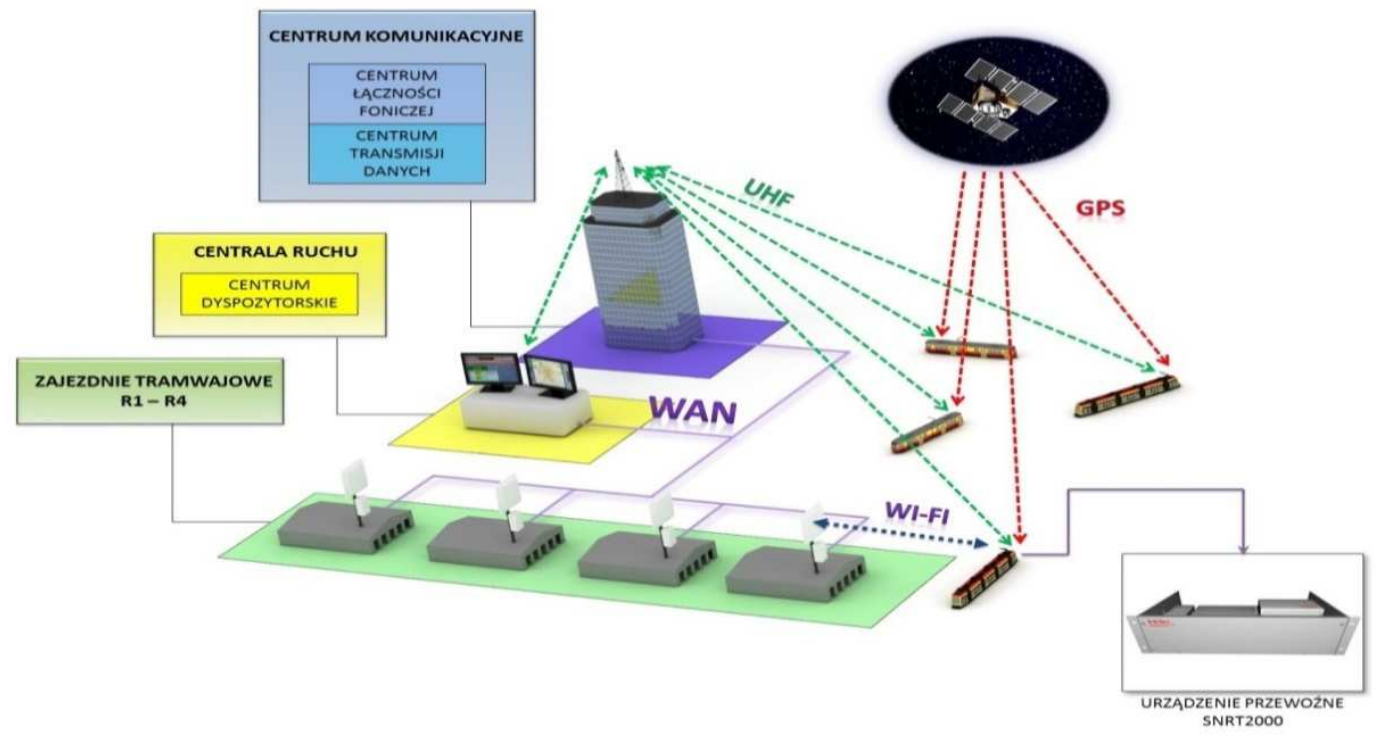

4. SNRT2000 system architecture, illustrating data transmission network [1]

The average length of polling for more than 400 vehicles is no more than 80 seconds. The message contains information about the time, minute and second of the local time, the train number, the GPS coordinates and the last stop unit on the route. Figure 5 shows data selected from messages.

$\begin{array}{llllll}06: 51: 45 & 3506 & 496907 & 5786689 & 5007 & \text { OS. WOLSKA } \\ 06: 51: 45 & 1391 & 500792 & 5785511 & 7005 & \text { PL.POLITECHNIKI } \\ 06: 51: 45 & 3023 & 498604 & 5784910 & 4004 & \text { OCH-TEATR } \\ 06: 51: 46 & 3267 & 498825 & 5789331 & 7091 & \text { RONDO "RADOSLAWA" } \\ 06: 51: 46 & 3275 & 502154 & 5791510 & 1078 & \text { STANIEWICKA } \\ 06: 51: 46 & 3118 & 502375 & 5791177 & 1077 & \text { RONDO ZABA }\end{array}$

5. Data messages, selected for assessing the accuracy of location trams [4]

The coordinates are given in the UTM (Universal Transverse Mercator) mapping. It uses the WGS84 ellipsoid and Mercator Transverse Mercator Projection. Warsaw is located in zone $34 \mathrm{U}$. The sent from the tramway dispatch tells the coordinates north and east with the accuracy of $1 \mathrm{~m}$.

As in the case of buses, the equation of a straight line simulating a tram route was calculated for each of the polygons, and then the distance from the GPS coordinates reported by the tram was calculated.

Analysis of the errors resulting from the multitude of GPS signal implies the choice of places with high development or small development of the nearby space. Measurement of high buildings is 
around the stops: Krucza 06, Hoża 04 and Wawelska 03. Poligones about lack of high buildings are around the stops: Poniatowskiego Bridge 04, Toruńska 04, PKP Rakowiec 03.

\section{GPS multitasking misstatements}

An example of a high-rise building is Dworzec Centralny, located at the junction of Al. John Paul II and Al. Jerusalem. In the vicinity there is a $105 \mathrm{~m}$ Golden Shopping Center, the Palace of Culture and Science with a height of $237 \mathrm{~m}$, a viaduct on the John Paul II Avenue and the Marriott Hotel.

Vehicles stopped at stops located on the northern carriageway of Central Station, in the immediate vicinity of the station building and under shelter. Each of the stops includes two bus lanes.

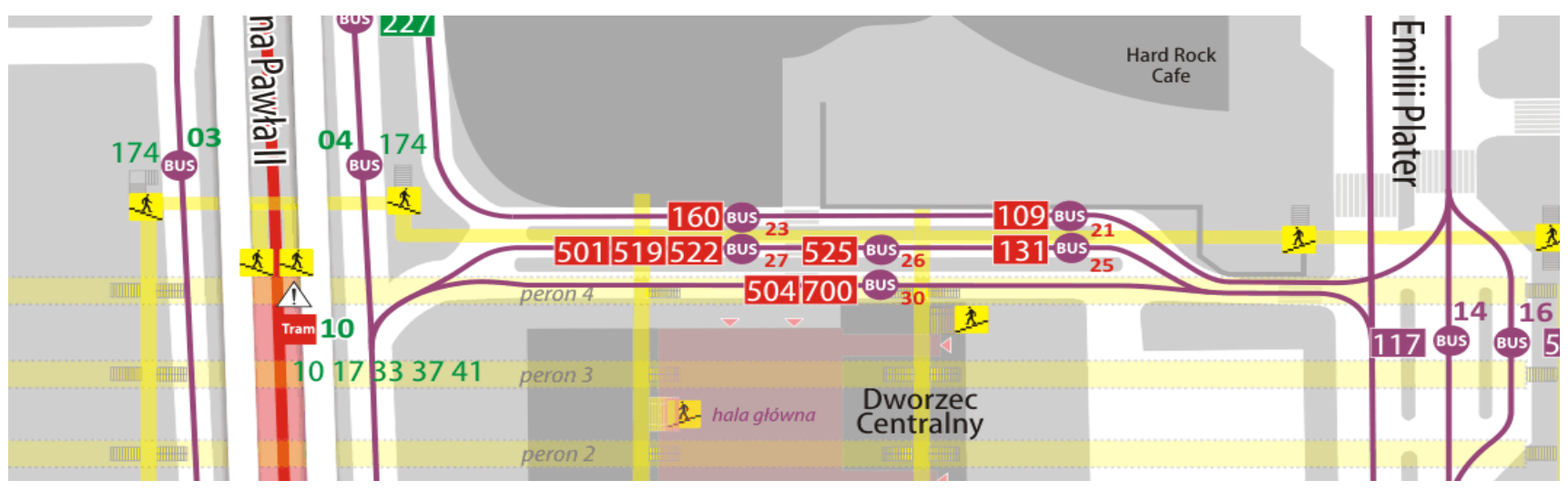

6. The location of the Dworzec Centralny stops [7]

The analyzes were based on telegrams sent in December 2012, January and February 2013, Based on 810 measurements, average error values and scatter results were obtained in high-rise areas and high probability of multiple signals. The results are presented in Table 2.

Tab. 2. Average error values of bus locations in high-rise areas [3]

\begin{tabular}{|c|c|c|c|}
\hline \multirow{2}{*}{$\begin{array}{c}\text { Stop number in the Central } \\
\text { Railway Station }\end{array}$} & \multirow{2}{*}{$\begin{array}{c}\text { Sample } \\
\text { size }\end{array}$} & \multicolumn{2}{|c|}{$\begin{array}{c}\text { Distance of the vehicle GPS receiver from the reference } \\
\text { line }\end{array}$} \\
\cline { 3 - 4 } & & Average value [m] & Standard deviation [m] \\
\hline 21,23 & 249 & 14,18 & 8,23 \\
\hline $25,26,27$ & 371 & 15,86 & 8,84 \\
\hline 30 & 190 & 17,39 & 13,17 \\
\hline
\end{tabular}

An example of an open space is the Osiedle Górczewska stop at Warsaw's Bemowo, at the junction of Górczewska and Lazurowa streets. There are no high buildings in the close vicinity. The analyses were based on signals from buses located at four marginal stops in the Osiedle Górczewska. The reference line was laid down along the platforms for bus stops at specific stops (see Table 3).

Tab. 3. Average bus location misstatements in low-rise areas [3]

\begin{tabular}{|c|c|c|c|}
\hline \multirow{2}{*}{$\begin{array}{c}\text { The number of the stop in } \\
\text { the Osiedle Górczewska } \\
\text { complex }\end{array}$} & \multirow{2}{*}{$\begin{array}{c}\text { Sample } \\
\text { size }\end{array}$} & \multicolumn{2}{|c|}{ Distance of the vehicle GPS receiver from the reference } \\
\cline { 3 - 4 } & & Average value [m] & Standard deviation [m] \\
\hline 04 & 533 & 4,64 & 2,99 \\
\hline 05 & 70 & 4,81 & 1,14 \\
\hline 06 & 400 & 7,54 & 5,71 \\
\hline 07 & 843 & 1,38 & 0,6 \\
\hline
\end{tabular}


Analysis of the accuracy of the location of the buses in the traffic was made on the section of Trasa Łazienkowska in the excavation, surrounded by tall buildings between ul. Marszałkowska and Al. Ujazdowskie.

Tab. 4. Average value of the misstatement of the buses position on the Trasa Łazienkowska [3]

\begin{tabular}{|c|c|c|}
\hline \multirow{2}{*}{ Sample size } & \multicolumn{2}{|c|}{ Distance of the vehicle GPS receiver from the reference line } \\
\cline { 2 - 3 } & Average value $[\mathrm{m}]$ & Standard deviation $[\mathrm{m}]$ \\
\hline 685 & 16,3 & $\mathbf{2 6 , 2 8}$ \\
\hline
\end{tabular}

An analysis of the accuracy of the location of buses in the open field was made on the section of the Silesian-Dabrowski Bridge in Warsaw (see Tab. 5).

Tab. 5. Average value of misstatement of the buses position on the Silesian-Dabrowski Bridge [3]

\begin{tabular}{|c|c|c|}
\hline \multirow{2}{*}{ Sample size } & \multicolumn{2}{|c|}{$\begin{array}{c}\text { Distance of the vehicle GPS receiver from the reference } \\
\text { line }\end{array}$} \\
\cline { 2 - 3 } & Average value [m] & Standard deviation [m] \\
\hline 1500 & 7,09 & 4,06 \\
\hline
\end{tabular}

The results of measurements of location accuracy in high and low building conditions, limited space (excavation) and free area indicate a significant influence of the environment on the location error.

Similarly, the accuracy of the location of tramways was determined. The locations in the center of Warsaw were chosen at:

- Al. Jerozolimskie in the neighborhood of junction with ul. Krucza (Krucza stop 06),

- Ul. Marszałkowska in the neighborhood of crossroads with ul. Hoża (Hoża stop 04),

- Ul. Grójecka in the neighborhood of the intersection with ul. Wawelska (Wawelska stop 03)).

Tab. 6. Average values of tram position misstatement at high construction [4]

\begin{tabular}{|c|c|c|c|}
\hline \multirow{2}{*}{ Place of measurement } & \multirow{2}{*}{$\begin{array}{c}\text { Sample } \\
\text { size }\end{array}$} & \multicolumn{2}{|c|}{$\begin{array}{c}\text { Distance of the vehicle GPS receiver from the reference } \\
\text { line }\end{array}$} \\
\cline { 3 - 4 } & & Average value [m] & Standard deviation [m] \\
\hline Krucza 06 & 744 & 9,07 & 10 \\
\hline Hoża 04 & 891 & 8,59 & 9,49 \\
\hline Wawelska 03 & 815 & 5,89 & 6,78 \\
\hline
\end{tabular}

The assessment was influenced by low development and when the tram track was running in the open area. Selected places are:

- $\quad$ Al. Krakowska viaduct over railway tracks (around the PKP Rakowiec stop 03),

- Ul. Rembelińska in the neighborhood of intersection with Tr. Toruńska (Toruńska stop 04)),

- $\quad$ Al. Jerozolimskie and Poniatowski Bridge (Poniatowski Bridge stop 04)).

Tab. 7. Mean values of the misstatement of the tram position in the open area [4]

\begin{tabular}{|c|c|c|c|}
\hline \multirow{2}{*}{ Place of measurement } & \multirow{2}{*}{$\begin{array}{c}\text { Sample } \\
\text { size }\end{array}$} & \multicolumn{2}{|c|}{$\begin{array}{c}\text { Distance of the vehicle GPS receiver from the reference } \\
\text { line }\end{array}$} \\
\cline { 3 - 4 } & & Average value [m] & Standard deviation [m] \\
\hline PKP Rakowiec 03 & 709 & 2,07 & 2,2 \\
\hline Toruńska 04 & 639 & 3,24 & 4,4 \\
\hline Most Poniatowskiego 04 & 787 & 3,88 & 5,32 \\
\hline
\end{tabular}


Tram location data were analyzed based on 757041 messages from 3 days in November 2014. The open areas are characterized by significantly smaller measurement errors. The biggest error was noted on the Poniatowski Bridge (most likely because of the bridge towers and the influence of buildings).

\section{Impact of devices on location accuracy}

It has been assumed that with the development of GPS technology, both processors, and software, the accuracy of the devices increases. Trams of Warsaw Trams are divided into two groups: new low-floor vehicles and older high-floor vehicles. Vehicle numbers were used to identify them. The results of the measurements confirmed the assumed assumption, the accuracy of the location has improved.

Tab. 8. Average value of position misstatement of different generation devices [4]

\begin{tabular}{|c|c|c|c|c|c|c|}
\hline \multirow[b]{2}{*}{$\begin{array}{c}\text { Place of } \\
\text { measurement }\end{array}$} & \multirow{2}{*}{$\begin{array}{c}\text { Generacja } \\
\text { urządzenia } \\
\text { GPS }\end{array}$} & \multirow[b]{2}{*}{$\begin{array}{l}\text { Sample } \\
\text { size }\end{array}$} & \multicolumn{4}{|c|}{$\begin{array}{l}\text { Distance of the vehicle GPS receiver from the reference } \\
\text { line }\end{array}$} \\
\hline & & & $\begin{array}{l}\text { Average } \\
\text { value }[\mathrm{m}]\end{array}$ & $\begin{array}{l}\text { Difference } \\
\text { of mean } \\
\text { value }[\mathrm{m}]\end{array}$ & $\begin{array}{c}\text { Standard } \\
\text { deviation }[\mathrm{m}]\end{array}$ & $\begin{array}{c}\text { Difference of } \\
\text { standard } \\
\text { deviation }[\mathrm{m}]\end{array}$ \\
\hline \multirow{2}{*}{$\begin{array}{l}\text { Wszystkie } \\
\text { lokalizacje } \\
\text { tramwajów }\end{array}$} & starszy tabor & 2162 & 6,44 & \multirow{2}{*}{1,46} & 8,02 & \multirow{2}{*}{2,53} \\
\hline & nowszy tabor & 2423 & 4,98 & & 5,49 & \\
\hline
\end{tabular}

\section{Summary}

In December 2012, January and February 2013, atmospheric conditions were observed and two days of extreme weather were selected. The analysis was made for a location with a medium error location for the Osiedle Górczewska stop. The data obtained from the buses on 2.02.2013 were investigated when heavy rainfall occurred, ranging between 7 and $14 \mathrm{~mm} / 12 \mathrm{~h}$ and on 13.12 .2012 without precipitation. The analysis shows that atmospheric conditions did not affect the accuracy of the location of GPS receivers.

The measure of the accuracy of the location was the GPS receiver's distance from its actual location. However, the vehicles did not always move on the track, interpolated by satellite imagery. Also accepted as location error, point distance from straight line. In fact, the vehicle could be in a different location than the point of sending a signal to a straight line. Certain errors are due to map inaccuracies (Google Earth Pro) and human eye. At Central Station, the stops are under shelter. The lines along the platforms that stopped the buses were estimated in an approximate manner.

It was not possible to determine which direction the vehicle was moving on the Lazienkowska and Silesian-Dąbrowski Bridge. An average reference line was established. For these reasons, the results obtained may be subject to errors resulting from the acceptance of the reference line as the actual track of the vehicle.

Tab. 9. Buses and trams location misstatements resulting from the multitrack of GPS signals

\begin{tabular}{|c|c|c|c|}
\hline \multirow{2}{*}{ Place of measurement } & \multirow{2}{*}{$\begin{array}{c}\text { Sample } \\
\text { size }\end{array}$} & \multicolumn{2}{|c|}{ Distance of the vehicle GPS receiver from the reference } \\
\cline { 3 - 4 } & & Average value [m] & Standard deviation $[\mathrm{m}]$ \\
\hline high-rise buses & 1495 & 15,97 & 17,27 \\
\hline buses with no development & 3346 & 5,26 & 3,14 \\
\hline high-rise trams & 2450 & 7,84 & 8,96 \\
\hline $\begin{array}{c}\text { trams with no } \\
\text { development }\end{array}$ & 2135 & 3,10 & 4,30 \\
\hline
\end{tabular}


Significant impact on the accuracy of satellite location is the nature of the building. This includes both buses and trams. In places with high and dense development, the resulting errors are 2 $\div 3$ times higher than in open areas.

\section{Source materials}

[1] Halak A. ,SNRT2000”, materiały firmy Infotron, http://www.infotron.com.pl/index.php/snrt-2000.

[2] Januszewski J.: „Systemy GPS i Inne Systemy Satelitarne w Nawigacji Morskiej”, Fundacja Rozwoju Wyższej Szkoły Morskiej w Gdyni, Gdynia 2004.

[3] Kita M.: Ocena dokładności lokalizacji pojazdów transportu publicznego w Satelitarnych Systemach Lokalizacji” praca inżynierska pod kierunkiem dr. J. Sudy Wydział Transportu PW, Warszawa 2014.

[4] Niedziółka M.: „Ocena dokładności satelitarnej lokalizacji tramwajów warszawskich” praca inżynierska pod kierunkiem dr. J. Sudy Wydział Transportu PW, Warszawa 2015.

[5] Pluto M.: „Identyfikacja metodą RFID”, Logistyka nr 1 / 2001.

[6] Sabak G.: „Wykorzystanie danych lokalizacji strumienia pojazdów w ITS - perspektywa operatora sieci komórkowych”, „ITS Przegląd” 2011, http://przeglad-its.p1/2011/03/18/

[7] Schematy rozmieszczenia linii komunikacyjnych http://www.ztm.waw.pl/mapy.php?c=117\&l=1

[8] Suda J.: „Efekty wprowadzania systemów zarządzania ruchem pojazdów miejskiej komunikacji publicznej”. II Konferencja Naukowo Techniczna „Zintegrowany transport publiczny w obsłudze miast i regionów Public Trans 2007", Warszawa 2007.

[9] Suda J.: „Wymagania funkcjonalne dla oprogramowania Sewera Łączności Alarmowej”. Opracowanie niepublikowane, wykonano dla MZA Sp. z o.o.. Warszawa 2012 r.

[10] Tracking Cell ID to location, materiały firmy Enaikoon, https://www.enaikoon.com/en/tools/cell-id-location/. 